\title{
Failure of ACTH to influence avoidance extinction in a one-way avoidance situation
}

\author{
D. ZISKIND, M. BAUM and Z. AMIT \\ Center for Research on Drug Dependence \\ Sir George Williams University, Montreal, P.Q., Canada \\ and \\ Université de Moncton, Moncton, New Brunswick, Canada
}

Forty rats were trained to avoid shock in a one-way automated ledge box. After acquisition of the avoidance response, the rats were administered an IP injection of Ringer's solution or one of three dosages of ACTH dissolved in Ringer's solution. Ten minutes after injection, the animal was replaced in the avoidance apparatus with the shock disconnected, and the number of trials required to extinguish the avoidance response was determined. This study was designed to determine if exogenous administration of whole ACTH could be shown to produce resistance to extinction of a shock avoidance, following the suggestion that the increase in resistance to extinction of shock avoidance observed after ethanol injections could be related to increased circulating ACTH levels. The results did not support the hypothesis that ACTH increases resistance to extinction in an active one-way shock avoidance situation.

A number of studies have investigated the role of ACTH in avoidance extinction (DeWied, 1966; Miller \& Ogawa, 1962; Murphy \& Miller, 1955). It has also been reported that adrenal steriods have the effect of shortening the number of trials required to extinction of an avoidance response (Levine, 1968). Since exogenous adiministration of ACTH stimulates adrenal steriod activity (DeWied, 1969), attempts have been made to study the effects on extinction of "ACTH analogues," which putatively have no gluco-corticoid stimulating properties but which in other respects are similar to whole ACTH (Bohus \& DeWied, 1966; Weijnen \& Slangen, 1969). The results of these manipulations to data are contradictory, Bohus and DeWied reporting inhibition of extinction with "ACTH analogues" and Weijnen and Slangen reporting no effect.

The authors became interested in the issue of ACTH effects on extinction in the course of a study of the effects of ethanol injections on the extinction of an active shock avoidance (Amit, Ziskind, \& Baum, 1973). It was suggested that the observed inhibition of extinction might result from an ACTH stimulating effect of ethanol injection (D. D. Thiessen, personal communication to M. Baum).

It was decided to test the effects of ACTH on active shock avoidance, using the same automated ledge-box apparatus and paradigm as that of the ethanol study by Amit et al.

Since a similar design had already been used (Weijnen \& Slangen, 1969) to test the effects of "ACTH analogues" and no effect was found, it was decided to use whole ACTH in spite of its gluco-corticoid stimulating effect.

\section{METHOD \\ Subjects}

Ss were 40 male rats of the Wistar strain obtained from Canadian Breeding Laboratories. They weighed 220-320 g during the course of acquisition and extinction of the avoidance response. All animals were housed in colony cages, two or three rats per cage, with water and Purina Rat Chow available ad lib.

\section{Apparatus}

The automated retractable ledge box with grid floor for providing shock was identical to that designed by Baum (1965).

\section{Procedure}

Intraperitoneal injections of ACTH (Acthar lyophilized porcine ACTH from Armour) dissolved in Ringer's solution of physiological saline were administered after acquisition of the avoidance response to a criterion of 10 consecutive avoidances. This form of ACTH acts rapidly. The animal was then kept in a plastic cage for $10 \mathrm{~min}$ before being replaced in the avoidance apparatus with the shock turned off for the extinction phase. This corresponds to the procedure used in Amit, Ziskind, \& Baum (1973) to test the effects of ethanol injections on avoidance extinction. The number of trials required to extinction of the avoidance response to a criterion of 5 consecutive minutes on the grid floor was counted.

Four groups were run: a control group $(\mathrm{N}=12)$ of animals received an IP injection of Ringer's solution $(1 \mathrm{cc} / \mathrm{kg})$ after acquisition (10 $\mathrm{min}$ before extinction); Group " 4 " $(\mathrm{N}=12)$ received 4 I.U. $/ \mathrm{kg}$ of ACTH dissolved in Ringer's solution (5 I.U./cc); Group " 8 " $(\mathrm{N}=9)$ received 8 I.U./kg of ACTH dissolved in physiological saline (4 I.U./cc); Group " 16 " $(\mathrm{N}=7)$ received $16 \mathrm{I} . \mathrm{U} . / \mathrm{kg}$ of ACTH dissolved in physiological saline (8 I.U./cc concentration).

\section{RESULTS}

A Kruskal-Wallis $\mathrm{H}$ test was used to analyze the data without making any assumption about the homogeneity of variance.

No significant effect on extinction due to ACTH administration was found $(\mathrm{H}=5.28$ corrected for ties, $\mathrm{df}$ $=3$ ). The median number of trials required to extinction and the range for each group is presented in Table 1.

\section{DISCUSSION}

Although no effect due to the administration of ACTH was found, there is still the possibility that the induction of gluco-corticoid secretion counteracted the ACTH effect on extinction (Finkelberg, 1971). However, using a similar avoidance apparatus, Weijnen \& Slangen (1969) also found no effect on extinction using an "ACTH analogue," which does not stimulate gluco-corticoid secretion, and DeWied (1966) has reported an increase in the number of trials required to

Table 1

Median and Range of Trials to Extinction

\begin{tabular}{lrcr}
\hline Treatment Group & $\mathrm{N}$ & Median & Range \\
\hline Ringer $(1 \mathrm{ml} / \mathrm{kg})$ & 12 & 13 & $4-136$ \\
ACTH $(4 \mathrm{IU} / \mathrm{kg})$ & 12 & 55.5 & $8-131$ \\
ACTH $(8 \mathrm{IU} / \mathrm{kg})$ & 9 & 81 & $0-204$ \\
ACTH $(16 \mathrm{IU} / \mathrm{kg})$ & 7 & 29 & $18-489$ \\
\hline
\end{tabular}


extinction of an active avoidance response in a design using whole ACTH.

The results of this study lend no support to the suggestion that ethanol-injection-produced increased resistance to extinction of an active shock is mediated by ethanol-induced ACTH secretion.

\section{REFERENCES}

Amit, Z., Ziskind, D., \& Baum, M. Drug effects and avoidance extinction in rats: $A$ test of the drug novelty hypothesis using ethanol. Animal Learning \& Behavior, 1973, 1, 41-43.

Baum, $M$. An automated apparatus for the avoidance training of rats. Psychological Reports, 1965, 16, 1205-1211.

Bohus, B., \& DeWied, D. Inhibitory and facilitory effect of two related peptides on extinction of avoidance behavior. Science, $1966,153,318-320$

DeWied, D. Inhibitory effect of $\mathrm{ACTH}$ and related peptides on extinction of conditioned avoidance behavior in rats. Proceedings of the Society for Experimental Biology \& Medecine, 1966, 122, 28-32.

DeWied, D. Effects of peptide hormones on behvior. In W. F. Ganong and L. Martini (Eds.), Frontiers in neuroendocrinology. New York: Oxford University Press, 1969. Pp. 97-140.
Finkelberg, F. Some effects of adrenocorticotrophic hormone and dexamethasone on behavior of the rat in the conditioned emotional response situation. Unpublished MA thesis, Sir George Williams University, 1970.

Levine, S. Hormones and conditioning. In W. J. Arnold (Ed.), Nebraska symposium on motivation. Lincoln: University of Nebraska Press, 1968. Pp. 85-101.

Miller, R. E., \& Ogawa, N. The effect of adreno-corticotrophic hormone (ACTH) on avoidance conditioning in the adrenolectomized rat. Journal of Comparative \& Physiological Psychology, 1962, 55, 211-213.

Murphy, J. V.. \& Miller, R. E. The effect of adrenocorticotrophic hormone (ACTH) on avoidance conditioning in the rat. Journal of Comparative \& conditioning in the rat. Journal of

Weïnen, J. A. W. M., \& Slangen, J. L. Effects of ACTH analogues on extinction of conditioned behavior. In $D$. DeWied and J. A. W. M. Weïnen (Eds.), Pituitary, adrenal and the brain. : Amsterdam: Elsevier, 1969. Pp. 221-235.

(Received for publication September 10, 1973.) 